\title{
International Exchange of Horticultural Crop Germplasm
}

\author{
George A. White \\ National Clonal Germplasm Repository, U.S. Department of Agriculture, Agricultural Research Service, \\ Davis, CA 95616
}

\section{Howard E. Waterworth \\ National Germplasm Resources Laboratory, U.S. Department of Agriculture, Agricultural Research Service, Glenn Dale, MD 20769}

Plant genetic resources provide the building blocks for improving yield, quality, pest resistance and tolerance, adaptability, and aesthetic value of horticultural crops. Ready access to a wide range of genetic diversity has contributed greatly to the abundance, high quality, and diversity of horticultural food and ornamental crops in the United States and elsewhere (White et al., 1989).

The movement of plant germplasm is affected by quarantine requirements of importing countries, status as endangered species, poor communications, lack of information, shipping perishable propagules (vegetative propagules and recalcitrant seeds), and property rights. Fortunately, seeds of most horticultural species are not quarantined and, therefore, are easily exchanged. In contrast, importing vegetative propagules are regulated by several countries. Most countries have welldefined import regulations, and all applicable regulations should be honored in exchanges. These regulations may require import permits (IP) issued by the plant protection services of the importing country and phytosanitary certificates (PC) issued by the plant protection services of the exporting country. The IP spells out the conditions under which the importer may receive desired plant material; it is a document signifying that the material has been inspected and certified by the exporting country as meeting the requirements of the importing country. When import requirements cannot be met, the options consist of no transaction or the plant protection service of the importing country agrees to either waive the requirements or test the material on receipt for the presence of the organism(s) of concern.

The enactment of the Convention on Biological Diversity (CBD) on 29 Dec. 1993 likely will have a significant impact on exchange and use of germplasm. Material Transfer Agreements (MTAs) that spell out specific details of how plant germplasm can be used and appropriate compensation may become commonplace.

In this paper, we discuss factors that affect exchange of horticultural crop germplasm, with emphasis on the import requirements of the United States. Ramifications of property

Received for publication 20 June 1995. Accepted for publication 29 Oct. 1995. We thank Joseph Foster, Kim Hummer, James Petit de Mange, Henry Shands, and Allan Stoner for editorial suggestions and Vicki Binstock for figure and manuscript preparation. The cost of publishing this paper was defrayed in part by the payment of page charges. Under postal regulations, this paper therefore must be hereby marked advertisement solely to indicate this fact.

HortScience, Vol. 31(3), June 1996 rights on exchanges also are discussed. Consideration is given to endangered species and to pathogen detection procedures for plant material introduced while in quarantine.

\section{IMPORTS INTO THE UNITED STATES}

Seed or vegetative propagule importers are responsible for complying with federal regulations and adhering to transit requirements. Seeds of most vegetable and flower species can be introduced without quarantine restrictions; however, they are subject to inspection on arrival and must be free from exotic pests, pathogens, noxious weeds, soil, and extraneous materials. However, some seeds, and especially vegetative propagules, may harbor potentially destructive exotic viruses, viroids, fungal and bacterial pathogens, and insects. Seeds should not be chemically treated unless required by the import permit.

The 1993 revision of the Code of Federal Regulations 7 (parts 300-399) includes the U.S. Dept. of Agriculture (USDA)-Animal Plant Health Inspection Service (APHIS) Foreign Quarantine Notices (part 319). Subpart 319.37 (Office of the Federal Register, 1993a) contains definitions, permit information, and listings of regulated plant species and plant parts. Information, permit application forms, and quarantine requirements for importing specific plant materials can be obtained from USDA-APHIS (see Table 3). Permits are required for importing and growing noxious weeds for research purposes and for inclusion in germplasm collections (Office of the Federal Register, 1993b).

\section{Quarantine categories}

The admissible category, which means that any plant material can be imported under certain safeguards, includes all horticultural species, except those listed as prohibited (Table 1). A nursery stock permit is required when $>12$ articles (other than seeds, bulbs, or orchid cultures) are introduced from any country, except Canada. Seeds of trees, shrubs, and many herbaceous perennial species require IP. The person requesting the permit must specify the port of entry. Permit items may enter the United States via any of the USDA-APHIS plant inspection stations.

Postentry permits require federal and state approval and allows the person requesting the permit to receive the medium-risk plant materials after affirmation of proper certification and inspection. These permits are required for a variety of horticultural crops. Most materials introduced under postentry permits are inspected on arrival by APHIS officials and are subject to inspection by state plant regulatory officials during two growing seasons. Certain other conditions, such as distance these imported plants can be planted from similar or related plants, also will apply. Some crops, such as Dianthus spp., must be grown in a greenhouse or other enclosed, pest-free building. Rubus must be grown in a screenhouse with 16-mesh screen (openings $\approx 1.1 \mathrm{~mm}$ ). The quarantine testing periods are normally 6 months for Chrysanthemum (from certain countries), 12 months for Dianthus, and two growing seasons all other items. If infected with exotic pathogens or pests, the clean-up will require more time. The Code of Federal Regulations lists 43 less-common fruit and nut genera, ranging from Achras and Annona to Vaccinium and Ziziphus, that require postentry permits.

Budwood of pome and stone fruit, if properly certified, can be introduced under postentry permit from Belgium, Canada, France, Germany, Great Britain, and The Netherlands. The locations that are approved sources for stone fruit able to enter under postentry permit are listed in Table 2. Pome fruit and cherries (Prunus spp.) can be imported from the same locations and from nurseries in the five European countries that participate in approved certification programs. A statement, similar to the following, must be included on the PC: "This material meets the specifications of the U.S. Quarantine Act, Article 7 CFR 319.375 (b), having been indexed for potential harmful viruses" or more simply "The requirements of CFR 319.37-5(b) have been observed." Indexing refers to procedures for testing plant material or its extracts to determine the presence of one or more pests. Because the approved sources may change, those importing stone fruit are advised to contact the Permit Unit of APHIS (see Table 3).

Because testing is not required for certified materials that have been imported from Belgium, France, Germany, Great Britain, and The Netherlands, the lengthy quarantine indexing period is avoided. However, the certified fruit trees must be grown in postentry quarantine for two growing seasons.

To import fruit genera from Canada that meet U.S. import regulations, a written permit and proper PC are required. There are no postentry growing requirements for properly certified fruit trees from Canada.

Plant items for propagation that are "prohibited," the most restrictive quarantine category, are able to enter the United States only under departmental permit. Most of this high- 
risk material must be introduced through the USDA National Plant Germplasm Quarantine Center, Beltsville, Md. The virus-indexing and testing for other exotic pests is a cooperative effort of APHIS and the Agricultural Research Service (ARS). Vegetative introductions of sweetpotato (Ipomoea spp.), apple (Malus spp.), stone fruit (Prunus spp.), pear (Pyrus spp.), and potato (Solanum spp.) (tubers and trueseeds), grasses, herbaceous legumes, and some woody ornamentals and shade trees must be virus-indexed at USDA facilities at Beltsville or Glenn Dale, Md. Seeds of stone fruit (except cherry, Prunus spp.) from countries known to have plum pox virus also must be indexed at the Maryland facilities unless properly certified by one of the five approved European countries as being derived from virus-free parental stock. Exceptions to the requirement for indexing at the Maryland facilities include properly certified fruit trees from the five European countries noted in Table 2 and Canada; fruit tree introductions that are to be indexed for a fee at Prosser, Wash. (mostly patented or protected cultivars for commercial use); all citrus (Citrus spp.); grapes (Vitis spp.); and strawberry (Fragaria spp.). The virus-indexing of potato conducted at the International Potato Center (CIP) Lima, Peru, is less inclusive than that of the United States. If one complete testing cycle by USDA gives negative results for introductions certified by CIP, the item can be released without undergoing a second testing cycle, which is required for potatoes from all other locations.

Assuming that the required permit conditions can be met, researchers may obtain departmental permits for growing avocado (Persea spp.), bamboo (tribe Bambuseae), barberry (Berberis spp.), coconut (Cocos nucifera L.), Mahonia spp., or mango (Mangifera spp.) from imported seeds in quarantine on their premises.

\section{Permit and import procedures}

After scientists or company officials identify horticultural germplasm of interest, they first need to attempt to determine whether such materials are available from a public or private germplasm collection. A query on the Germplasm Resources Information Network will show if a particular item has been recorded in the database as being in the National Plant Germplasm System (NPGS). Because the material or similar materials may be in the United States but not recorded in the database, contact with the appropriate crop curator and crop experts also is advised. Additionally, the Seed Savers 1994 Yearbook (Whealy, 1994) and the Cornucopia, a Source Book of Edible Plants listing (Facciola, 1990) might be helpful in locating sources of a wide range of horticultural crop germplasm. If the materials are not in the United States, the entry requirements for introducing them from a foreign country should be determined. If not restricted, the source can be contacted directly for the desired materials. For restricted materials, it will be necessary to apply for an IP from the

Table 1. Quarantine category, countries involved, and primary pathogens and insects of concern for importing restricted vegetative propagules of selected fruit, ornamental, and vegetable germplasm into the United States. ${ }^{2}$

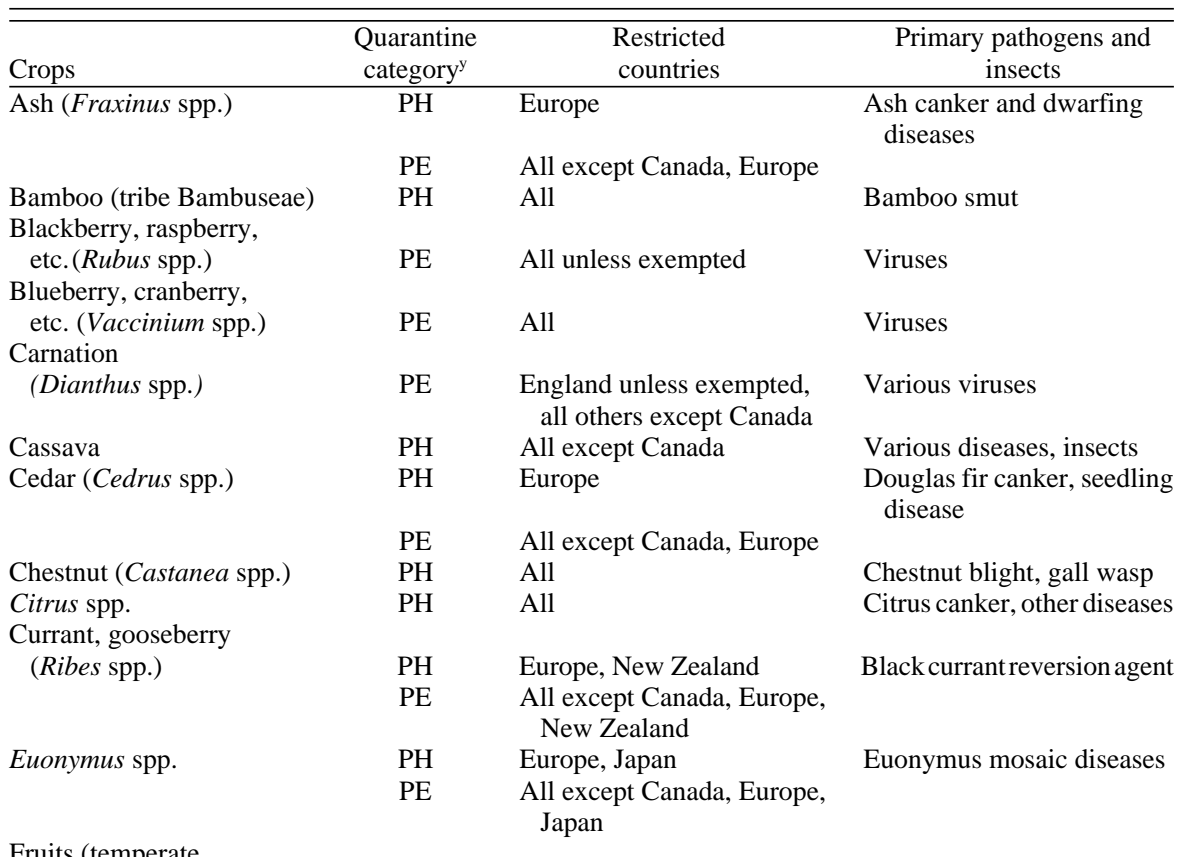

Fruits (temperate tree $)^{\mathrm{x}}$

Gladiolus spp.
(except corms)

Grape

Grasses

(vegetative portions)

Hydrangea

arborescens $\mathrm{L}$.

Jasmine (Jasminum spp.)

$\mathrm{PH}$

PE

All unless properly certified Various viruses, diseases

Properly certified from

Canada, Belgium, England,

France, Germany,

The Netherlands

Africa, parts of South

America and Europe

PE All except Canada, those above

PH All except Canada with certification

$\mathrm{PH}$

All except Canada

PH Japan

PE All except Canada, Japan

$\mathrm{PH}$ Belgium, Germany,

England, India,

Philippines

PE All except Canada, those above

Juniper

(Juniperus spp.)

Kiwi (Actinidia spp.)

Leguminous plants (herbaceous)

Lilac (Syringa spp.)

Mahonia spp. and

Mahoberberis spp.

Maple (Acer spp.)

Mountain ash

(Sorbus spp.)

Europe

PE All except Canada, Europe

PH All except Can

PE All except Australia,

Canada, New Zealand, and those above
$\mathrm{PH}$

$\mathrm{PH}$

PE

All

Europe

Netherlands with certification, all others except Canada, Europe

PH All nonresistant types

PE All resistant types except to eradication states

PH Europe, Japan

PE All except Canada, Europe, Japan

PH Czech Republic and Slovakia, Denmark, Germany
Rusts

Various diseases, viruses

Aecidium sp.

Several viruses

Needlecast disease, Douglas fir canker

Rust

Viruses

Elm mottle disease

Black stem rust

Certain bacteria, viruses Variegation or ringspot
mosaic

Continued on next page 
Table 1. continued

\begin{tabular}{|c|c|c|c|}
\hline Crops & $\begin{array}{l}\text { Quarantine } \\
\text { category }^{\mathrm{y}}\end{array}$ & $\begin{array}{l}\text { Restricted } \\
\text { countries }\end{array}$ & $\begin{array}{c}\text { Primary pathogens and } \\
\text { insects }\end{array}$ \\
\hline & PE & $\begin{array}{l}\text { All except Canada, } \\
\text { those above }\end{array}$ & \\
\hline \multirow[t]{2}{*}{ Mulberry (Morus spp.) } & $\mathrm{PH}$ & $\begin{array}{l}\text { India, Japan, Korea, China, } \\
\text { Thailand, former Soviet } \\
\text { Union }\end{array}$ & $\begin{array}{l}\text { Mulberry dwarf, mosaic } \\
\text { diseases }\end{array}$ \\
\hline & $\mathrm{PE}$ & $\begin{array}{l}\text { All except Canada, } \\
\text { those above }\end{array}$ & \\
\hline \multirow{3}{*}{$\begin{array}{l}\text { Mums } \\
\text { (Chrysanthemum spp.) }\end{array}$} & & & \\
\hline & $\mathrm{PH}$ & $\begin{array}{l}\text { Europe, parts of South } \\
\text { America and Africa, Asia, } \\
\text { Oceania, others }\end{array}$ & White rust \\
\hline & $\mathrm{PE}$ & $\begin{array}{l}\text { All except Canada, } \\
\text { those above }\end{array}$ & \\
\hline Nut and fruit items ${ }^{w}$ & $\mathrm{PE}$ & All & Various diseases \\
\hline $\begin{array}{l}\text { Okra, hibiscus } \\
\text { (Abelmoschus spp., }\end{array}$ & $\mathrm{PH}$ & $\begin{array}{l}\text { Africa, Brazil, some Asian } \\
\text { countries }\end{array}$ & Various viruses \\
\hline Hibiscus spp.) & $\mathrm{PE}$ & $\begin{array}{l}\text { All except above and } \\
\text { Canada }\end{array}$ & \\
\hline $\begin{array}{l}\text { Passion fruit } \\
\text { (Passiflora spp.) }\end{array}$ & $\mathrm{PE}$ & All except Canada & \\
\hline \multirow{3}{*}{$\begin{array}{l}\text { Pine (two and three-leafed) } \\
\text { (Pinus spp.) }\end{array}$} & & & \\
\hline & $\mathrm{PH}$ & Europe, Japan & $\begin{array}{l}\text { Stunting rust, gall-forming } \\
\text { rust }\end{array}$ \\
\hline & PE & $\begin{array}{l}\text { All except Canada, Europe, } \\
\text { Japan }\end{array}$ & \\
\hline \multicolumn{4}{|l|}{ Plumegrass } \\
\hline Potato & $\mathrm{PH}$ & All except Canada & Viruses, nematodes \\
\hline Privet (Ligustrum spp.) & $\mathrm{PH}$ & Europe & Liqustrum mosaic diseases \\
\hline \multirow[t]{2}{*}{ Rose (Rosa spp.) } & $\mathrm{PH}$ & $\begin{array}{l}\text { Australia, Bulgaria, } \\
\text { Italy, New Zealand }\end{array}$ & Rose wilt disease \\
\hline & $\mathrm{PE}$ & $\begin{array}{l}\text { All except Canada, those } \\
\text { above }\end{array}$ & \\
\hline \multirow[t]{2}{*}{ Strawberry } & $\mathrm{PH}$ & $\begin{array}{l}\text { All except Canada and } \\
\text { Israel }\end{array}$ & Red stele disease \\
\hline & $\mathrm{PE}$ & $\begin{array}{l}\text { All except Canada, those } \\
\text { above }\end{array}$ & \\
\hline Sweetpotato & $\mathrm{PH}$ & All except Canada & Various viruses \\
\hline \multirow[t]{2}{*}{ Willow (Salix spp.) } & $\mathrm{PH}$ & $\begin{array}{l}\text { Germany, England, } \\
\text { The Netherlands }\end{array}$ & Watermark disease \\
\hline & $\mathrm{PE}$ & Europe except those above & \\
\hline
\end{tabular}

${ }^{\mathrm{z}}$ Adapted from Foreign Quarantine Notices (Office of the Federal Register, 1993a).

${ }^{\mathrm{y}} \mathrm{PE}=$ postentry; $\mathrm{PH}=$ prohibited.

xThese include apple, quince (Cydonia spp.), pear, and the genus Prunus.

whese include cashew (Anacardium spp.), papaya (Carica spp.), filbert (Corylus spp.), persimmon (Diospyros spp.), fig (Ficus spp.), walnuts (Juglans spp.), Macadamia spp., mango, avocado, date (Phoenix spp.), pistachio (Pistacia spp.), and others.

Permit Unit, APHIS, or to contact the National Germplasm Resources Laboratory (NGRL), Beltsville, Md. In addition to identifying the materials wanted, the person making the request should provide the NGRL with the names and addresses of sources and indicate how the material will be used. Also, any known restrictions on the use of the materials because of property rights should be detailed in writing.

Packages of plant materials from foreign sources must include identification of the materials, the country of origin, the sender (name and address), and the intended recipient. Unidentified plant materials are automatically considered prohibited. Quarantine mailing labels will be provided by the Permit Unit, APHIS, to the person requesting the permit. NGRL staff can provide labels with appropriate permit numbers for materials that must be quarantined at the Maryland facilities. Plant materials should be sent by mail, air express, or air freight in sturdy containers. Air express is recommended for perishable vegetative propagules and recalcitrant (short-lived) seeds.
Budsticks and other cuttings should be slightly dampened and put in plastic bags; however, samples that are too wet often rot enroute. The sender or importer pays for air express shipments and any airport charges.

Tables 1 and 4 are intended to serve as a guide to import-restricted germplasm into the United States. The steps to follow for introducing plant materials are shown schematically in Fig. 1.

\section{Quarantine and detection of pathogens}

A primary reason for prohibiting entry of certain foreign germplasm is the presence of exotic virus-like pathogens in some overseas locations (Parliman and White, 1985; Waterworth and White, 1982). Among the pathogens targeted by testing procedures are viruses, viroids, mycoplasmas, and other uncharacterized infectious agents (Office of the Federal Register, 1993a; Waterworth, 1993). Keeping foreign pathogens out of the United States begins by closely observing the inventory of quarantined plants for symptoms of disease during plant growth (Fig. 2). This step is followed by a battery of tests for latent pathogens.

The methods used to detect viruses include enzyme-linked immunosorbant assay (ELISA), electron microscopy, mechanical transmission of expressed sap from the germplasm to known virus-sensitive herbaceous species, nucleic acid hybridization, and polymerase chain reaction (PCR) plus gel electrophoresis. These tests are conducted in specially constructed quarantine laboratories and greenhouses. Other infectious entities, for which there are no rapid tests, can be detected only by grafting tissues from the imported plant onto known pathogen-sensitive plants of the same genus. These indicator plants then are observed for a designated period, depending on the crop and suspect agent, for disease symptoms. While some agents incite symptoms on vegetative tissue within 2 months, others cause symptoms only in the fruit, which necessitates a test of several years on fruiting trees in an isolated orchard (Fig. 3). Different test combinations, which are mutually agreed on by APHIS and ARS, are used for each species to detect as many pathogens as possible (Table 5). For example, pears are tested for $\approx 20$ virus-like agents by grafting budwood into healthy indicators, while potato accessions are tested for a similar number of pathogens by ELISA, a chemiluminescent dot blot probe, and mechanical transmission of sap to virus-sensitive herbaceous indicator plants (Fig. 4). Stone fruit are tested for $\approx 70$ viruslike agents by ELISA, mechanical sap transmission, and graft tests to woody indicators.

The percentage of accessions in which one or more pathogens were detected during the $1983-93$ period ranged from $<1 \%$ of the cacaos (Theobroma spp.) to $56 \%$ of the potato accessions (Table 6). Multiple viral infections, especially in potatoes and apples, are not uncommon. Usually the method of detection, combined with evaluations by experienced personnel, results in the identification of the pathogens, many of which are already in the United States, but because it is the policy of the NPGS not to distribute germplasm known to contain even domestic viruses, attempts are made to obtain pathogen-free germplasm whenever possible.

The pathogen testing program is supported by research that focuses on improving detection methods. The goal of the research is to detect pathogens with less effort, more reliably, more rapidly, or by less costly procedures. For example, a PCR method has been developed but not yet adopted as a routine procedure to detect latent viroids in stone fruit (Shamloul et al., 1994) and a chemiluminescent hybridization protocol is available to detect viroids in apple and potato germplasm (Podleckis et al., 1993). Improved procedures for pathogen detection are adopted for routine use as they become available (Bliss et al., 1994). The expanded use of PCR methods in pathogen detection is anticipated because reliable results can be obtained quickly with small amounts of plant tissue (Hadidi et al., 1995). 
When an introduced germplasm accession is infected, several courses of action are available depending on the crop. One is to test other plants of the same accession. If all are infected, the choices are 1) attempt re-importation of the germplasm; 2) distribute pollen or seed, which is usually not quarantined, from the accession; or 3) perform heat therapy on the

Table 2. Locations of approved sources for stone fruit enterable under postentry permit.

\section{Belgium}

Fruit and Vegetable Research Station, Chaussée de Charleroi, 5030 Gembloux

Gorsem Research Center, Brede Akker 3, 3800 Sint-Truiden

\section{France}

CTIFL, Le Centre d'Amélioration de la Production de Balandran, 30 Bellegarde

CTIFL, Centre d'Lanxade, 24130 Prigonrieux

INRA, Centre de Recherches de Bordeaux, Domaine de La Grande Ferrade, B.P. 81, 33883 Villenave d'Ornan Cedex

\section{Germany}

Biologische Bundesanstalt, Institut für Pflanzenschutz im Obstbau, Postfach 1264, Schwabenheimer Str. 101, 69221 Dossenheim

Bayerische Landesanstalt für Bodenkultur und Pflanzenbau, Postfach 380269, Menzinger Str. 54, 80638 München

Bayerische Landesanstalt für Weinbau und Gartenbau, An der Steige 15, 97209 Veitshöchheim

Hessisches Landesamt für Regionalentwicklung und Landwirtschaft, Pflanzenschutzdienst, Am Versuchsfeld 17, 34128 Kassel

Institut für Angewandte Botanik, Abteilung Pflanzenschutz, Virologie, Postfach 302762, Marseiller Str. 7 , 20355 Hamburg

Institut für Pflanzenschutz, Saatgutuntersuchung und Bienenkunde, Nevinghoff 40, Postfach 5980, 48147

Münster

Landesamt für Ernährung, Landwirtschaft und Flurneuordnung, Referat Pflanzenschutz, Ringstr. 1010, Postfach 379, 15236 Frankfurt/Markendorf

Landesanstalt für Pflanzenschutz, Reinsburgstr. 107, 70197 Stuttgart

Landesanstalt für Pflanzenbau und Pflanzenschutz Rheinland-Pfalz, Essenheimer Str. 144, 55128 Mainz

Landespflanzenschutzamt, Mecklenburg-Vorpommern, Abt. Pflanzenbeschau, Graf-Lippe-Str. 1, 18059

Rostock

Landespflanzenschutzamt, Sachsen-Anhalt Halle, Sitz Magdeburg, Zum Waldsee 1, 39114 Magdeburg

Landwirtschaftskammer Hannover, Pflanzenschutzamt, Wunstorfer Landstr. 9, Postfach 9108 10, 30453

Hannover

Landwirtschaftskammer Rheinland, Pflanzenschutzamt, Postfach 300864, Siebengebirgsstr. 200, 53229

Bonn

Landwirtschaftskammer Saarland, Postfach 462, Lessingstrasse 12-14, 66121 Saarbrücken

Pflanzenschutzamt des Landes Schleswig-Holstein, Westring 383, Postfach 3548, 24118 Kiel

Sächsische Landesanstalt für Landwirtcschaft, Pflanzenschutzamt Dresden, Stübelalle 2, 01307 Dresden

Staatl. Lehr- und Versuchsanstalt für Wein- und Obstbau Weinsburg, Postfach 1309, Traubenplatz 5, 74185

Weinsburg

Thüringer Landesverwaltungsamt, Referatsgruppe Landwirtschaft, Sachgebiet Pflanzenschutz, Carl-

August-Allee 2a, Postfach 249, 99423 Weimar

Universität Bonn, Institut fur Obst- und Gemüsebau, Auf dem Hügel 6, 53121 Bonn

\section{Great Britain}

Horticultural Research International, East Malling, Maidstone, Kent ME19 6BJ

The Netherlands

NAK-D Nuclear Stockfield or Multiplication Plots, Noordoost Polder Zeewolde, Contact: Plant Protection Service, Geertjewweg 15, Wageningen

Table 3. Key U.S. contacts relative to the international exchange of horticultural crop germplasm.

Import-export requirements; certification information; postentry quarantine

U.S. Dept. of Agriculture, National Plant Germplasm Quarantine Center, Bldg. 580, BARC-East,

Beltsville, MD 20705; phone +301.504.8141; fax +301.504.8539

Convention on International Trade in Endangered Species of Wild Fauna and Flora and Endangered Species

Act species import-export permits

U.S. Fish and Wildlife Service, Office of Management Authority, P.O. Box 3507, Arlington,

VA 22203-3507; phone +703.358.2104

Import permit application, import requirements

Permit Unit, U.S. Dept. of Agriculrure-Animal Plant Health Insepction Service-PPQ, 4700 River Rd., Unit 136, Riverdale, MD 20737-1236; phone +301.734.8645; fax +301.734 .5786$

Assistance with plant germplasm exchanges

National Germplasm Resources Laboratory, U.S. Dept. of Agriculture-Agricultural Research Service, Bldg. 003, Rm. 400, 10300 Baltimore Ave., Beltsville, MD 20705; phone +301.504.5328; fax $+301.504 .6305$

Indexing time and procedures, status of plants in quarantine

Plant Germplasm Quarantine Office, National Germplasm Resources Laboratory, Bldg. 580, BARCEast, Beltsville, MD 20705; phone +301.504 .8630 ; fax +301.504 .8397$

National database queries

Germplasm Resource Information Network, National Germplasm Resources Laboratory, U.S. Dept. of Agriculture-Agricultural Research Service, Bldg. 003, Rm. 407, BARC-West, 10300

Baltimore Ave., Beltsville, MD 20705; phone +301.504.5318; fax +301.504.5536;

e-mail gopher.ars-grin.gov; http://www.ars-grin.gov

accession in an effort to produce disease-free tissue. Heat treatment or meristem culture is employed regularly in the program on infected apple, pear, potato, sweetpotato, and cassava (Manihotspp.) germplasm. Following therapy, treated plants and tissues are retested to ensure that the previously detected pathogens have been eliminated, and the original infected plant is destroyed. Germplasm released from quarantine is routinely made available to the importing scientist and usually to the appropriate germplasm repository.

To expedite the availability of germplasm, a conditional release program is approved for pome and stone fruit after preliminary tests give negative results and before final readings are taken (Waterworth, 1993). To receive conditionally released germplasm, recipients must obtain permission from their state regulatory office. Recipients will be expected to agree to certain restrictions on how this germplasm can be grown and propagated until its unconditional release from quarantine.

\section{EXPORTS FROM THE UNITED STATES}

Most countries have regulations that govern importing plant materials. Representatives from $>100$ countries signed an agreement (International Plant Protection Convention) to honor the import requirements of all signatories. The usual requirement is the issuance of a PC by the exporting country that certifies that each of the listed requirements of the importing country have been met. In general, countries that impose strict conditions on imports of specific crops and their close relatives will usually require an IP and a PC. The import permit may require additional declarations (AD), such as freedom from specific pathogens. The individual making the request then must obtain the IP from his or her country's plant protection service and send it to the germplasm supplier.

Import requirements vary widely among countries and species. For example, some countries, including Algeria, Argentina, Chile, Czech Republic, India, Israel, Mexico, New Zealand, South Africa, Turkey, and former Yugoslavia, require IPs and PCs for importing all or most species. Egypt, Ghana, Greece, and Iran restrict vegetable seed imports in general, and France, Germany, Ghana, Great Britain, Italy, and The Netherlands specifically restrict tomato (Lycopersicon spp.) seed imports. In contrast, the European Union (EU, formerly European Community) countries do not require PCs for seeds of many species. However, because of variations in individual EU country regulations, U.S. suppliers of plant materials are advised to check with state or federal quarantine officials or USDA plant germplasm inspection station personnel.

Several problems related to import regulations that make exchanges difficult include the following: 1) some countries call for certification of freedom from a long list of diseases; 2) an $\mathrm{AD}$ may be required that a specific disease(s) does not occur in the source country or in the production area of the supplied materials; 3 ) 
the time necessary for issuance of an IP is excessive; 4) the importer fails to obtain an IP, and 5) there is no pathogen-negative source of the requested material.

Foreign requestors desiring U.S. plant germplasm should identify clearly the materials needed, indicate a source if known, enclose an IP if required, and provide environmental information for the plant's culture (rainfall, elevation, minimum and maximum temperatures, etc.) if specific cultivars or lines are not known. Requests can be sent directly to known sources, curators of collections, or NGRL for the desired crops.

If the importing country requires a $\mathrm{PC}$, the U.S. supplier should obtain one from local,

Table 4. Countries and primary pathogens and insects of concern for introducing regulated seeds of selected fruit, ornamental, and vegetable germplasm into the United States.

\begin{tabular}{|c|c|c|}
\hline Crops & $\begin{array}{c}\text { Restricted } \\
\text { countries }\end{array}$ & $\begin{array}{l}\text { Primary pathogens and } \\
\text { insects }\end{array}$ \\
\hline Avocado & $\begin{array}{l}\text { Central and South America, Mexico, } \\
\text { certain others }\end{array}$ & Avocado moth and weevil \\
\hline $\begin{array}{l}\text { Bamboo } \\
\text { (Tribe Bambuseae) }\end{array}$ & All & Bamboo smut \\
\hline $\begin{array}{l}\text { Chestnut, oak } \\
\text { (Quercus spp.) }\end{array}$ & All except Canada and Mexico & Various insects \\
\hline $\begin{array}{l}\text { Lentil (Lens spp.), } \\
\text { sweetpea }{ }^{2} \text { Lathyrus } \\
\text { odoratus L.) }\end{array}$ & All except Central and North America & Insects (Bruchidae family) \\
\hline Mango & $\begin{array}{l}\text { All except North and South America, } \\
\text { certain others }\end{array}$ & Mango weevil \\
\hline Okra, hibiscus $^{2}$ & All & Pink bollworm \\
\hline Potato (tps) & $\begin{array}{l}\text { All except Canada, Chile (with } \\
\text { certification), New Zealand }\end{array}$ & Viruses \\
\hline $\begin{array}{l}\text { Prunus }^{\mathrm{y}} \text { (except } \\
\text { subgenus Cerasus) }\end{array}$ & Europe, Cyprus, Syria, Turkey, Chile & Plum pox (sharka) virus \\
\hline Rutaceae family ${ }^{z}$ & Many countries except Europe & Citrus canker \\
\hline $\begin{array}{l}\text { Seeds (all kinds } \\
\text { when in pulp) }\end{array}$ & All except Canada & Fruitflies, other insects \\
\hline
\end{tabular}

${ }^{2}$ Exempt from quarantine if treated by Plant Protection and Quarantine at port of entry.

'Seeds of other Prunus species are admissible if properly certified from Belgium, England, France, Germany, and The Netherlands and from all other unnamed countries if accompanied by a phytosanitary certificate stating that plum pox does not occur in the country in which the seeds were produced.

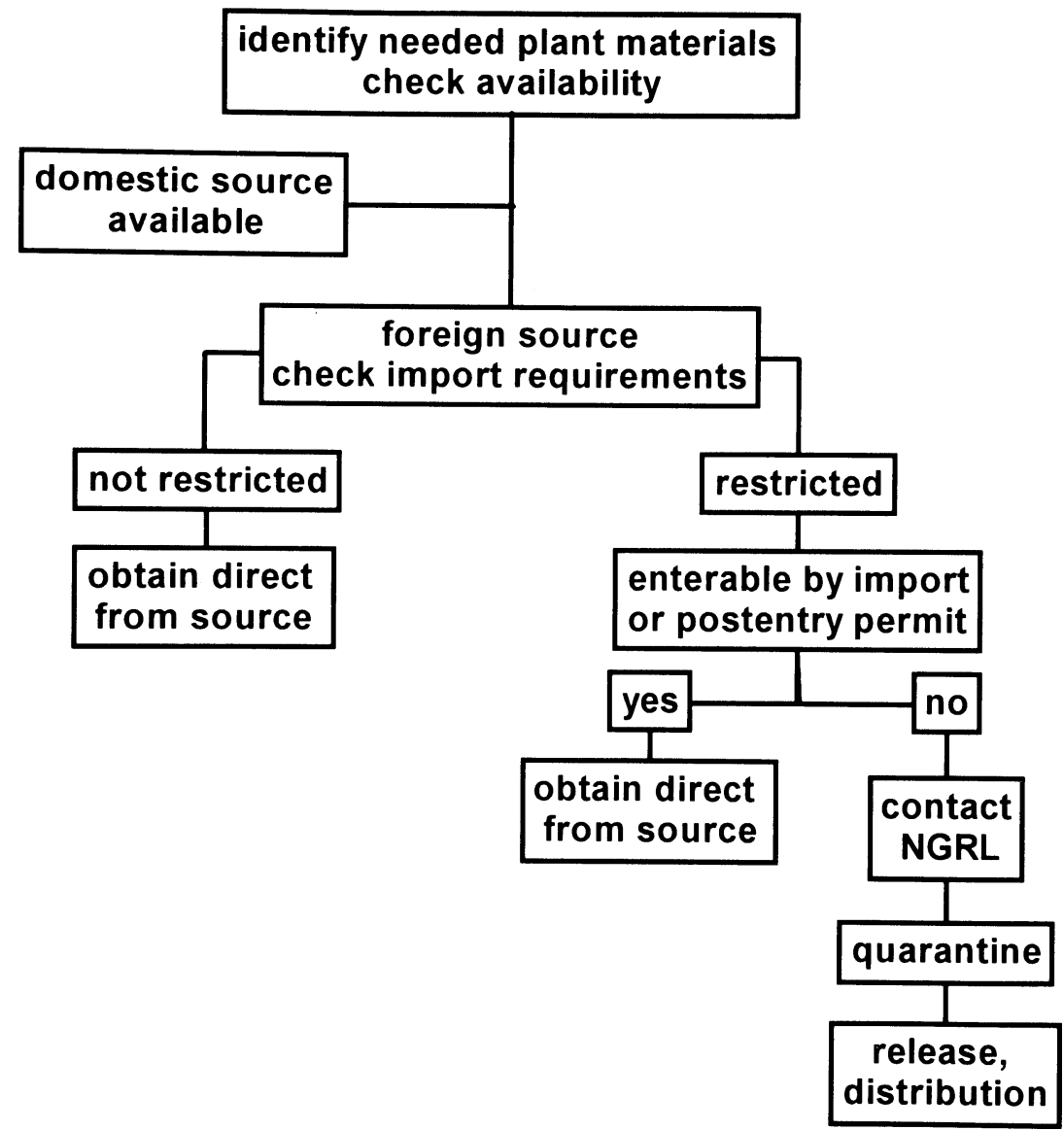

Fig. 1. Importing foreign horticultural crop germplasm by the United States for research and evaluation trials. state, or federal officials. These officials can provide additional information concerning ADs, acceptability of state or federal PCs, the need for an import permit, etc. Alternatively, the supplier may send the material through the NGRL to the USDA Plant Germplasm Inspection Station for issuance of the PC. A check or money order made out to APHIS (currently \$23.00) should be enclosed with the plant material to cover the cost of the PC. Required ADs usually will not be known until an import permit is received. Inspection station staff can only issue PCs if inspection before export is required, not if field inspection is necessary.

The steps for foreign researchers to follow to introduce horticultural crop germplasm from the United States are outlined schematically in Fig. 5.

\section{ENDANGERED SPECIES}

The Convention on International Trade in Endangered Species of Wild Fauna and Flora (CITES) and the U.S. Endangered Species Act (ESA) of 1973 (pending renewal) affect exchanges of endangered species. The documentation required for exchanging germplasm of endangered species is separate and distinct from that specified by plant quarantine regulations. A general permit is required for commercial imports, exports, or re-exports of terrestrial plants encompassed by CITES and ESA. Applications (PPQ form 621) can be obtained from the Permit Unit, APHIS.

The introduction of certain endangered species into the United States requires a CITES-IP that is available from the U.S. Fish and Wildlife Service (FWS). A CITES import permit is not required for some plants; however, an export or re-export permit or an export certificate of artificial propagation from the country of origin is required for all CITES protected plants. Seeds or vegetative propagules of endangered species that arrive in the United States without CITES documentation will be confiscated at the port of arrival. To export CITES-protected plants of U.S. origin, an export permit must be obtained from the FWS.

There are 21 plant families with species of horticultural interest that require a CITES import permit for importation into the United States. These include Agavaceae, Cactaceae (34 species and all species of five genera), Euphorbiaceae (nine species of Euphorbia), Liliaceae (five species of Aloe), and Orchidaceae (nine species and all species of two genera).

\section{PROPERTY RIGHTS}

Intellectual property rights, farmers' rights, breeders' rights, MTAs, patents, utility patents, plant variety protection, access to genetic resources, and testing agreements are terms that have become familiar to users of plant genetic resources. The CBD became effective on 29 Dec. 1993; but it may be several years before its impact on exchanges and field collecting of plant genetic resources is known (Shands, 1994). There are many questions that 


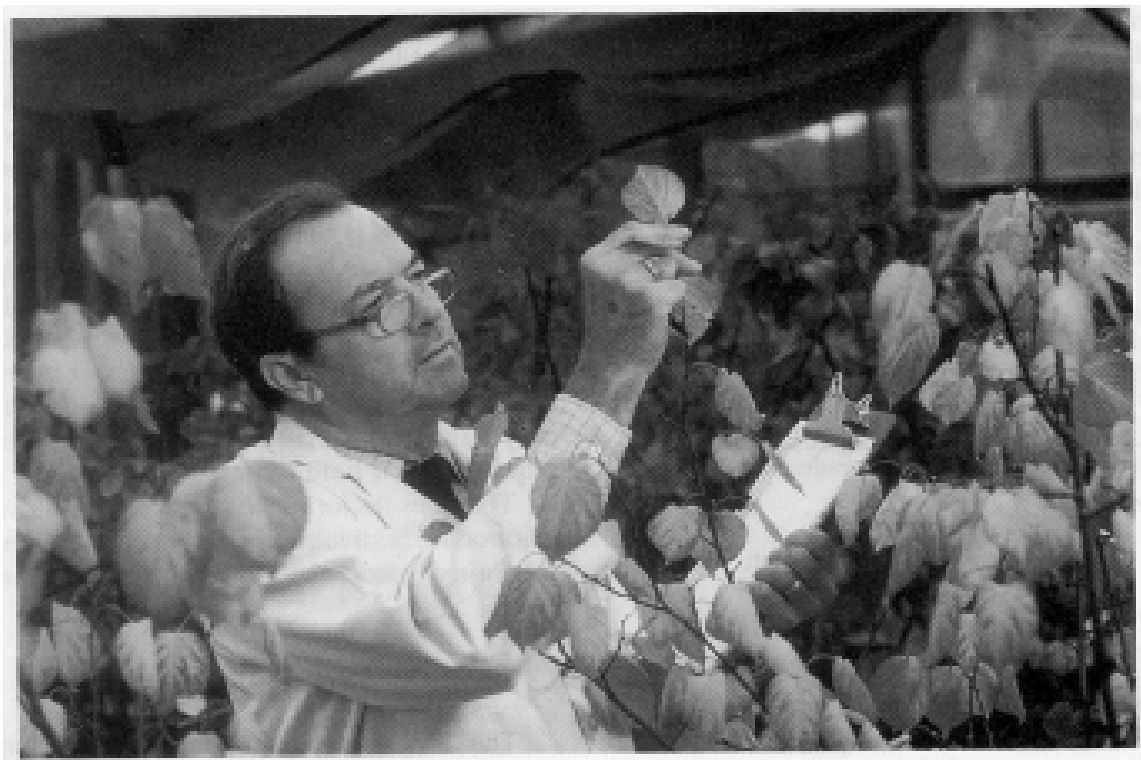

Fig. 2. Stone fruit germplasm is closely examined for symptoms of diseases while in quarantine.

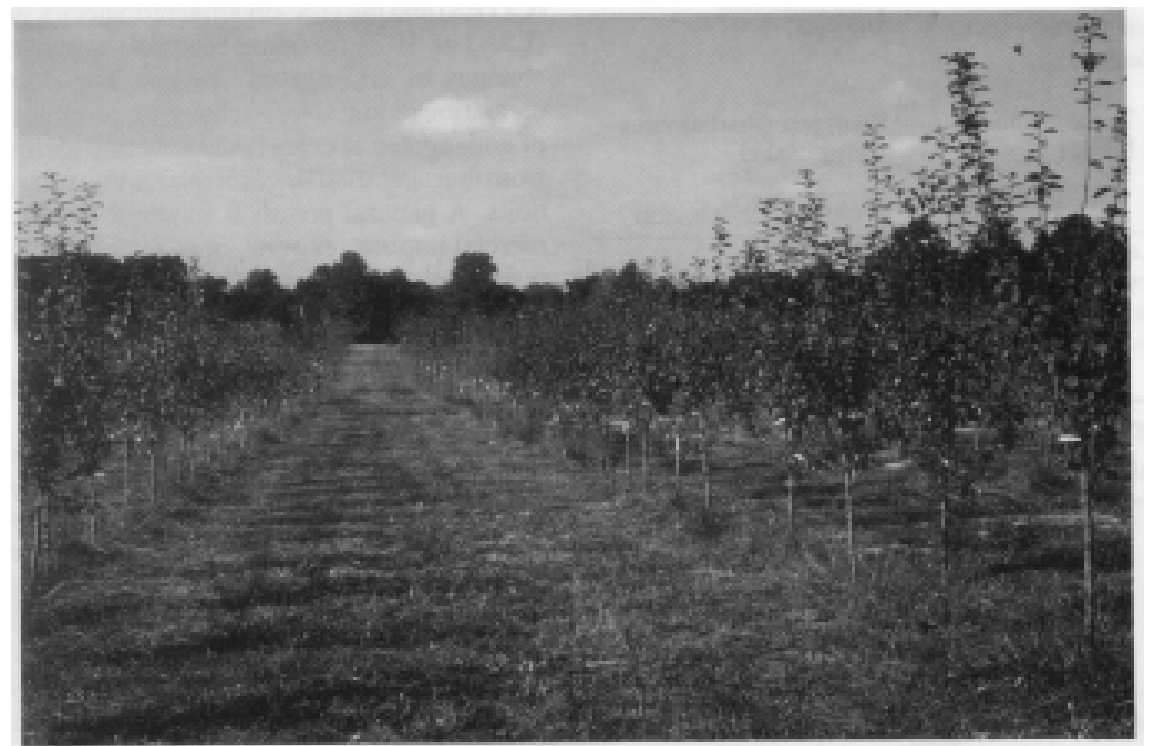

Fig. 3. Typical, field test block of apple germplasm to detect pathogens that produce symptoms only in fruit.

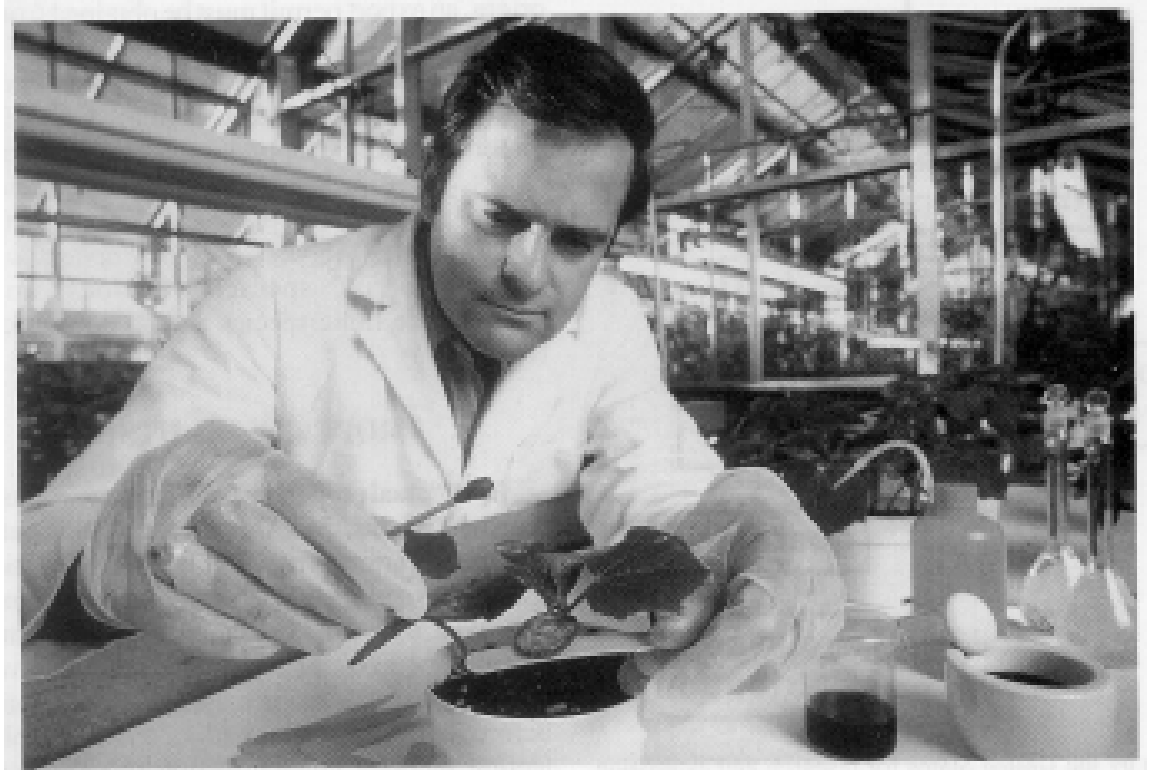

Fig. 4. Technician conducting sap transmission test for viruses in potato germplasm. remain to be answered: Who owns germplasm assembled in national and international genebanks before and after CBD? How will the distribution and use of germplasm be accurately and efficiently tracked? How is the value of genes from landraces or wild species assessed? How are farmers to be compensated for their contributions of germplasm? Will restricted usage and compensation for usage of genetic resources significantly reduce exchanges? Will there be an exemption for research usage and, if so, what will its limits be?

Apparently, the MTA will be the main and, in effect, legal document to specify the usage, especially for research purposes, of plant genetic resources. The MTA may address financial arrangements, which could range from none, to an up-front payment per accession, to a percentage of profits from use in a commercial product. Moreover, some form of legal property protection for genetic material also is included in the General Agreement on Tariffs and Trade.

A research exemption may be part of international agreements pertaining to plant germplasm (Plowman, 1993). We favor retaining free-exchange policies. In any case, conditions for use of genetic resources should be agreed on before embarking on field explorations or exchanges. The responsibility for usage and compensation rests with the supplier

Table 5. Tests required by the U.S. Dept. of Agriculture-Animal Plant Health Inspection Service on some of the plant genera in the prohibited quarantine category.

\begin{tabular}{lcc}
\hline \hline Genus & $\begin{array}{c}\text { Quarantine } \\
\text { duration (years) }\end{array}$ & Tests $^{\mathrm{z}}$ \\
\hline $\begin{array}{l}\text { Abies } \\
\text { Acer }\end{array}$ & 1 & $\mathrm{O}$ \\
$\begin{array}{l}\text { Fraxinus } \\
\text { Bambuseae } \\
\quad \text { Tribe) }\end{array}$ & 3 & $\mathrm{O}, \mathrm{ST}, \mathrm{G}$ \\
Jasminum & 1 & $\mathrm{O}$ \\
Ipomoea & 1 & $\mathrm{O}$ \\
Malus & $2-3$ & $\mathrm{O}, \mathrm{ST}, \mathrm{G}$ \\
Morus & 5 & $\mathrm{O}, \mathrm{S}, \mathrm{G}$ \\
Pinus & 3 & $\mathrm{O}, \mathrm{G}$ \\
Prunus & 1 & $\mathrm{O}, \mathrm{ST}, \mathrm{G}$ \\
Ribes & 5 & $\mathrm{O}$ \\
Saccharum & 4 & $\mathrm{O}, \mathrm{ST}, \mathrm{G}, \mathrm{S}$ \\
Solanum & 2 & $\mathrm{O}, \mathrm{ST}, \mathrm{G}$ \\
Theobroma & 2 & $\mathrm{O}, \mathrm{S}, \mathrm{ST}, \mathrm{ST}, \mathrm{NA}$ \\
The & 3 & $\mathrm{O}, \mathrm{G}$ \\
\hline
\end{tabular}

${ }^{\mathrm{z}} \mathrm{O}=$ observation for pathogens and diseases, $\mathrm{ST}=$ sap transmission for viruses, $\mathrm{G}=$ graft tests in indicator cultivars, EM = electron microscopy, $\mathrm{S}=$ serology, $\mathrm{HT}=$ heat treatment, $\mathrm{NAP}=$ nucleic acid probe .

Table 6. Percentage of quarantined accessions infected with virus or virus-like agents from 1985 to 1994.

\begin{tabular}{lc} 
Crop & Infected (\%) \\
\hline Potatoes & 56 \\
Apples & 50 \\
Sweetpotatoes & 48 \\
Pears & 35 \\
Small fruits & 20 \\
Stone fruits & 15 \\
Woody ornamentals & 5 \\
Sugarcane & \\
$\quad$ Saccharum spp.) & 1 \\
Cacao & $<1$ \\
\hline
\end{tabular}




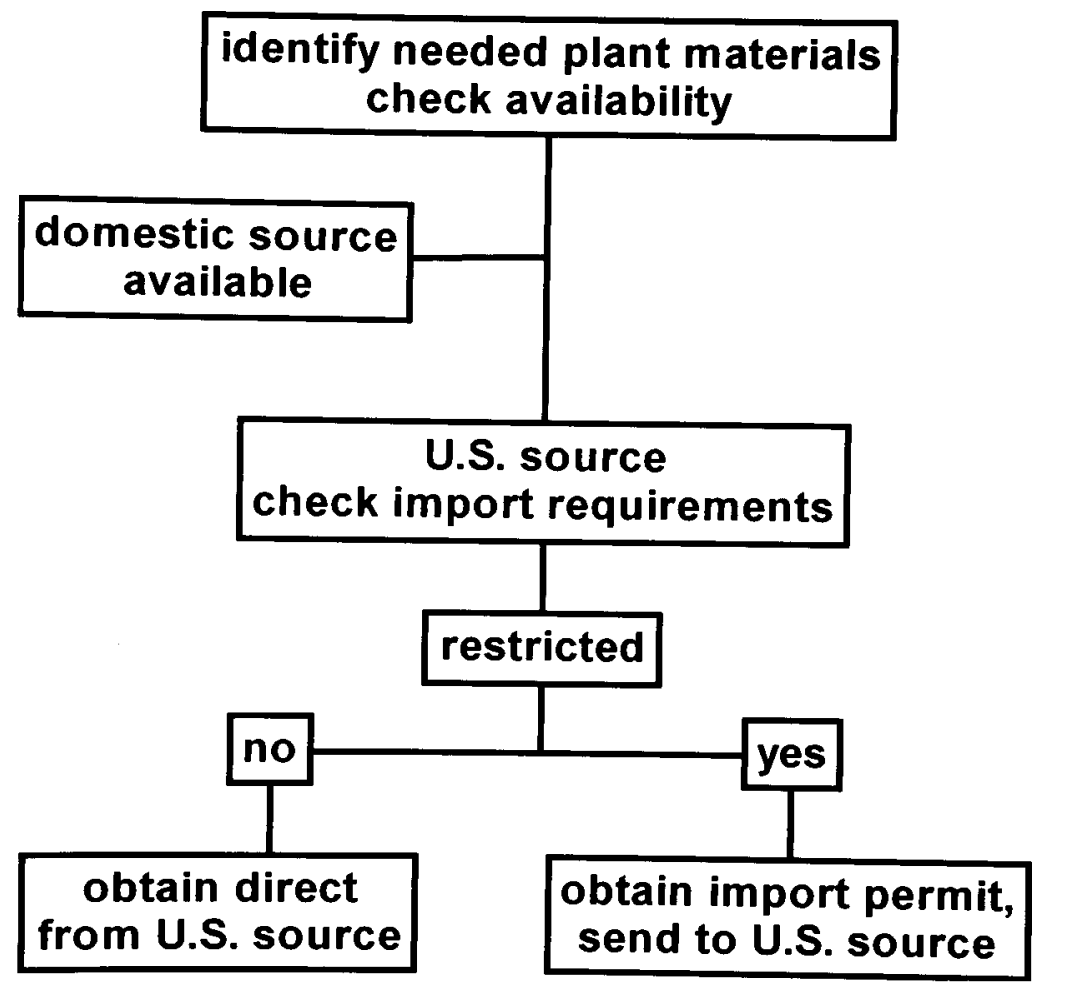

Fig. 5. Importing U.S. horticultural crop germplasm by foreign countries for research and evaluation trials.

and the recipient of the plant material. A case in point is the policy of the Royal Botanical Gardens in Kew, England. Most items on their List of Seeds (Linington, 1994) are collected from the wild in various countries. To receive seeds, the person requesting them must sign an agreement that a portion of the profits derived from any commercial use of these materials will be provided to Kew Gardens. The monies then are divided between Kew Gardens and the country of origin. Under this agreement, any distribution of seeds from Kew Gardens would have to be tracked and reported to Kew Gardens. The current U.S. procedure is to provide the seed to the appropriate germplasm collection curator and, after increase, make it available to researchers worldwide without restrictions, thus circumventing the Kew requirement.

Scientists generally engage in two-way exchanges of plant genetic resources with foreign colleagues. Joint publication and releases often ensue when exchanged materials are significant in the parentage of improved materials. Possible ramifications of intellectual property rights were addressed extensively by Baenziger et al. (1993) before final approval of the CBD.

\section{Literature Cited}

Baenziger, P.S., R.A. Kleese, and R.F. Barnes (eds.). 1993. Intellectual property rights: Protection of plant materials. Crop Sci. Soc. Amer. Special Publ. 21.

Bliss, W.O., C.L. Sutula, H.E. Waterworth, and R.W. Fulton. 1994. An ELISA to detect American plum line pattern ilarvirus. Phytopathology 84(10): 1131.

Facciola, S. 1990. Cornucopia, A source book of edible plants. Kampong Publications, Vista, Calif.

Hadidi, A., L. Levy, and E.V. Podleckis. 1995.
Polymerase chain reaction technology in plant pathology, p. 167-186. In: Advanced methods in plant pathology. CRC Press, Boca Raton, Fla.

Linington, S. (ed.). 1994. List of seeds 1994. Seed Bank, Royal Botanic Gardens, Kew, England.

Office of Federal Register. 1993a. Code of federal regulations, Title 7-Agriculture, 7CFR 319.37. Subpart-Nursery stock, plants, roots, bulbs, seeds, and other plant parts, p. 182-211. Office of Federal Register, Washington, D.C.

Office of Federal Register. 1993b. Code of federal regulations, Title 7-Agriculture, 7CFR 360. Part-Noxious weed regulations, p. 364-367. Office of Federal Register, Washington, D.C.

Parliman, B.J. and G.A. White. 1985. The plant introduction and quarantine system of the United States. Plant Breeding Rev. 3:361-434.

Plowman, R.D. 1993. Intellectual property rights in plants-An ARS perspective. Diversity 9(1,2):74-76

Podleckis, E.V., R.W. Hammond, S.S. Hurtt, and A. Hadidi. 1993. Chemiluminescent detection of potato and some fruit viroids by digoxigeninlabeled dot blot and tissue blot hybridization. J. Virol. Methods 43:147-158.

Shamloul, A.M., A. Minafra, A. Hadidi, L. Giunchedi, H.E. Waterworth, and E.K. Allum. 1995. Peach latent mosaic viroid: Nucleotide sequencing of an Italian isolate, sensitive detection using RT-PCR and geographic distribution. Acta Hort. 386:522-530.

Shands, H.L. 1994. Who owns the world's plant genes? Agr. Res. September:2.

Waterworth, H.E. 1993 Processing foreign plant germplasm at the National Plant Germplasm Quarantine Center. Plant Dis. 77(9):854-860.

Waterworth, H.E. and G.A. White. 1982. Plant introduction and quarantine: The need for both. Plant Dis. 66(1):87-90.

Whealy, K. 1994. Seed Savers 1994 yearbook. Seed Savers Exchange, Decorah, Iowa.

White, G.A., H.L. Shands, and G.R. Lovell. 1989. History and operation of the National Plant Germplasm System. Plant Breeding Rev. 7:5-56. 